\title{
STUDI PERENCANAAN PEMBANGUNAN PLTMH DI KAMPUNG SASNEK DISTRIK SAWIAT KABUPATEN SORONG SELATAN PROVINSI PAPUA BARAT
}

\author{
Politeknik Katolik Saint Paul Sorong \\ Markus Dwiyanto Tobi Sogen, ST., MT; Vina Natalia Van Harling, S.Si., M.Pd \\ Email : dwiyanto@poltekstpaul.ac.id; vina.nathalia@poltekstpaul.ac.id
}

\begin{abstract}
Abstrak
Listrik sangat dibutuhkan oleh seluruh lapisan masyarakat. Kampung Sasnek merupakan salah satu kampung yang terletak di Distrik Sawiat Kabupaten Sorong Selatan Provinsi Papua Barat. Kampung sasnek letaknya sangat terpencil dan dihuni sekitar 100KK. Kampung ini belum terlayani listrik oleh PLN hingga saat ini. Pembangkit listrik mikro hidro adalah pembangkit listrik skala kecil yang kapasitasnya berkisar antara $100 \mathrm{~W}$ sampai dengan $100 \mathrm{~kW}$. Studi perencanaan ini bertujuan merencanakan dan nantinya akan ke tahap implementasi Pembangkit Listrik mikro hidro dengan kapasitas daya 12 Volt DC, karena merupakan salah satu cara pembangkit listrik yang paling ekonomis, muda dan aman. pengukuran debit air, didapat debit sebesar 2 liter/detik dari luas area pengukuran $5 \mathrm{~m}^{2}$ dan kecepatan air rata-rata $00.65 \mathrm{~m} / \mathrm{d}$. Namun karena kondisi air sungai yang mengalir sepanjang tahun dalam arti tidak pernah kering, maka digunakan faktor koreksi 0.75 . Dengan demikian debit yang bisa dimanfaatkan adalah sebesar $0.65 \mathrm{~m}^{3} /$ d. Berdasarkan hasil analisa terhadap potensi PLTMH yang terdapat di Sasnek, maka dapat dikalkulasikan Distribusi Jaringan Listrik yang bersumber dari PLTMH Sasnek adalah $10 \mathrm{KW}$. Dengan adanya perencanaan yang matang sehingga hasil implementasinya akan memberikan dampak yang postif akan pemenuhan kebutuhan listrik di kampung sasnek dan juga kampung sekitarnya.
\end{abstract}

Kata Kunci : PLTMH, Mikro Hidro, Pembangkit Listrik

\section{PENDAHULUAN}

\subsection{Latar Belakang}

Energi listrik merupakan energi yang tidak bisa lepas dari kehidupan masyarakat. Kegiatan dan kebutuhan manusia dalam kesehariannya tidak terlepas dengan adanya listrik. Negara Indonesia merupakan negara yang banyak memiliki potensi sumber energi terbarukan yang hingga kini belum di manfaatkan secara optimal. Potensi energi terbarukan yang sudah di manfaatkan sebagian besar berupa sungai yang air-nya cenderung terbuang ke laut. Padahal setiap kilometer sungai dapat dimanfaatkan sebagai sumber tenaga untuk menggerakan pembangkit listrik tenaga mikro hidro.

Pemanfaatan energi terbarukan ini dapat dioptimalkan terutama di lokasi pedesaan atau kampung, yang umumnya tersebar dan juga tidak memungkinkan untuk mendapatkan layanan jaringan PLN. Karena itu perlu dilakukan beberapa usaha, yakni membangun pembangkit sendri yang terpisah dari jaringan PLN. Salah satunya adalah pembangkit listrik tenaga mikro hidro sebagai salah satu alternatif energi nasional.

Melalui konsep mikro hidro "Power Pal System" ini, masyarakat di wilayah perkampungan di Provinsi Papua Barat yang belum menikmati listrik dapat terpenuhi. Hal ini menjadi alasan utama karena keterbatasan suplay daya listrik dari PLN bisa di atasi. Tenaga air dalam pemanfaatan untuk pembangkit tenaga listrik dibagi dalam tiga kategori yaitu skala besar, mini, dan mikro. Belum ada ketentuan secara jelas mengenai pembagian skala tersebut. Tampaknya setiap negara mempunyai aturan yang berbeda. Namun, secara umum tenaga air (hydropower) skala besar mempunyai kapasitas di atas $10 \mathrm{MW}$. Mini berkapasitas $200 \mathrm{~kW}$ sampai $10 \mathrm{MW}$, dan mikro berkapasitas sampai $200 \mathrm{~kW}$ (Sumber : Departemen Energi dan Sumber Daya Mineral, 2003). Potensi tenaga air di seluruh Indonesia secara teoritis diperkirakan sekitar 75.000 MW yang tersebar pada 1.315 lokasi. Tenaga air merupakan salah satu potensi sumber energi yang sangat besar, tetapi pemanfaatannya 
masih jauh di bawah potensinya. Dan potensi tersebut diperkirakan sebesar 34.000 MW, dapat dikembangkan untuk pusat pembangkit tenaga listrik dengan kapasitas cukup besar, 100 MW (Sumber : Departemen Energi dan Sumber Daya Mineral 2003) .

Pembangkit Listrik Tenaga Mikro hidro adalah salah satu konsep pembangkit tenaga listrik yang dihasilkan melalui tenaga air dengan skala kecil. Dimana melalui konsep ini, aliran air yang di modifikasi sedemikian rupa dan memenuhi kriteria "Power Pal System" sehingga akan menghasilkan tenaga listrik, yang kemudian di suplay ke konsumen. Penerapan konsep tenaga listrik mikro hidro ini, dapat berguna bagi masyarakat yang hidup di daerah perkampungan dan memiliki potensi air cukup baik, sehingga memberikan solusi bagi penyediaan tenaga listrik di wilayah tersebut. Melalui konsep "microhydro power pal system", masyarakat di wilayah perkampungan yang sampai saat ini belum menikmati lampu penerangan atau listrik minimal dapat terpenuhi.

\subsection{Perumusan Masalah}

Kampung Sasnek merupakan salah satu kampung yang terletak di Distrik Sawiat Kabupaten Sorong Selatan Provinsi Papua Barat. Kampung ini terdiri dari \pm 170 KK dan merupakan salah satu kampung terpencil yang sampai saat ini belum dapat menikmati adanya penggunaan listrik. Sehingga kerap kali masyarakat di kampung ini merasakan adanya ketidakadilan dalam hal kebijakan PLN dalam melistriki Papua, karena sampai saat ini kampung tersebut belum dapat dialiri sumber daya listrik PLN. Kampung sasnek memiliki 3 (tiga) aliran sumber air terjun, yang pada dasarnya memiliki kapasitas jika dimanfaatkan untuk membangkitkan listrik. Hal ini menjadi alasan utama peneliti untuk dapat memberikan kontribusi ilmu pengetahuan dengan melakukan kajian dan studi tentang pembangunan PLTMH di kampung sasnek Distrik Sawiat Kabupaten Sorong Selatan, Provinsi Papua Barat. Hasil penelitian ini nantinya akan digunakan sebagai bahan implementasi pembangunan PLTMH di kampung tersebut. Penelitian ini akan mengkaji dengan batasan yakni, analisis tenaga air yang ada dan jenis turbin yaknis crossflow, serta bagaimana rancangan instalasi tenaga listrik dan distribusi beban.

\subsection{Maksud dan Tujuan}

Maksud dan tujuan dari penelitian ini adalah untuk melakukan studi perencanaan dalam menyiapkan suatu sistem energi listrik dengan memanfaatkan energi potensial air yang tersedia di Kampung Sasnek, yang berlokasi di Distrik Sawiat Kabupaten Sorong Selatan Provinsi Papua Barat. Sehingga dalam implementasi pembangunan PLTMH tersebut kedepannya, dapat memberikan manfaat langsung bagi warga kampung Sasnek, guna peningkatan produktivitas ekonomi dan keberlangsungan hidup masyarakat kampung Sasnek.

\section{TINJAUAN PUSTAKA}

\subsection{Konsep Mikrohidro}

Menurut (Parabelem T.D. Rompas, Jurnal Penelitian Saintek, Vol. 16, Nomor 2, Oktober 2011); Mikrohidro adalah istilah yang digunakan untuk instalasi pembangkit listrik yang menggunakan energi air. Kondisi air yang bisa dimanfaatkan sebagai sumber daya (resources) penghasil listrik adalah memiliki kapasitas aliran dan ketinggian tertentu dan instalasi. Semakin besar kapasitas aliran maupun ketinggiannya dari instalasi maka semakin besar energi yang bisa dimanfaatkan untuk menghasilkan energi listrik Prinsip dasar mikrohidro adalah memanfaatkan energi potensial yang dimiliki oleh aliran air pada jarak ketinggian tertentu dari tempat instalasi pembangkit listrik. Sebuah skema mikrohidro memerlukan dua hal yaitu, debit air dan ketinggian jatuh (head) untuk menghasilkan tenaga yang dapat dimanfaatkan (Gambar 2.1). Hal ini adalah sebuah sistem konversi energi dari bentuk ketinggian dan aliran (energi potensial) ke dalam bentuk energi mekanik dan energi listrik. Daya yang masuk ( $\left.\mathrm{P}_{\text {gross }}\right)$ merupakan penjumlahan dari daya yang dihasilkan $\left(\mathrm{P}_{\text {net }}\right)$ ditambah dengan faktor kehilangan energi (loss) dalam bentuk suara atau panas. Daya yang dihasilkan merupakan perkalian dari daya yang masuk dikalikan dengan efisiensi konversi $\left(\sum \mathbf{\eta}\right)$. 


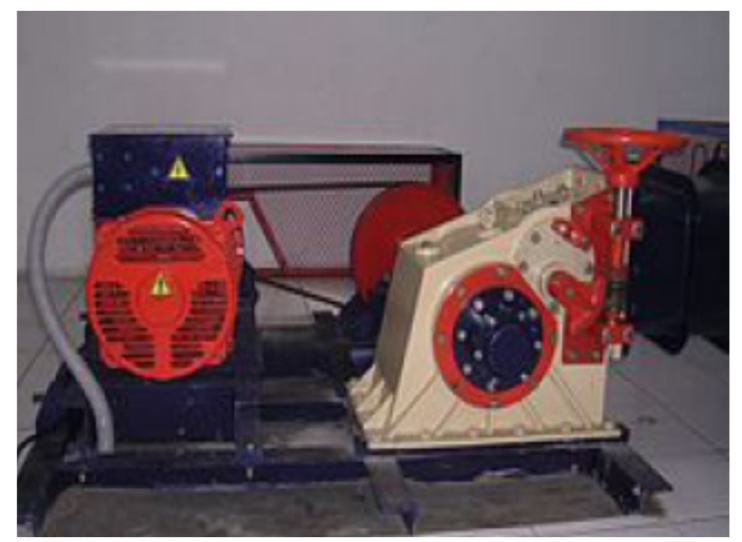

Gambar 2.1 Mikrohidro Tipe Cross flow

\subsection{Cara Kerja PLTMH Secara Umum}

Menurut (Sri Sukamta dan Adhi Kusmantoro, Jurnal Teknik Elektro Universitas Negeri Semarang, Jurnal Teknik Elektro Vol. 5 No. 2 Juli - Desember 2013) ; Aliran sungai dibendung agar mendapatkan debit air (Q) dan tinggi jatuh air $(\mathrm{H})$, kemudian air yang dihasilkan disalurkan melalui saluran penghantar air menuju kolam penenang, Kolam penenang dihubungkan dengan pipa pesat, dan pada bagian paling bawah di pasang turbin air. Turbin air akan berputar setelah mendapat tekanan air (P), dan perputaran turbin dimanfaatkan untuk memutar generator, Setelah mendapat putaran yang constan maka generator akan menghasilkan tegangan listrik, yang dikirim kekonsumen melalui saluran kabel distribusi (JTM atau JTR).

Menurut (Yogi Suryo Setyo Putro, Pitojo Tri Juwono, dan Prima Hadi Wicaksono, Jurnal Ilmiah Universitas Brawijaya 2012) ; Prinsip dasar kerja dari PLTMH adalah memanfaatkan air sungai yang diarahkan ke dalam saluran pembawa kemudian dialirkan melalui pipa pesat menuju turbin. Selepas dari turbin, air dikembalikan lagi ke aliran semula, sehingga hal ini tidak banyak mempengaruhi lingkungan atau mengurangi air untuk keperluan pertanian. Air akan dialirkan ke dalam turbin melalui sudu-sudu runner yang akan memutarkan poros turbin. Putaran inilah yang akan memutar dan menggerakkan generator untuk menghasilkan listrik.

\subsection{Diagram Skematis Pembangkit Listrik Tenaga Mikro Hidro}

Menurut (Ir. Janter Napitupulu, MT, Jurnal DA, Jurusan Teknik Elektro Universitas Darma Agung Medan, 2012) ; Diagram skematis PLTMH dapat digambarkan sebagai berikut (gambar 2.2).

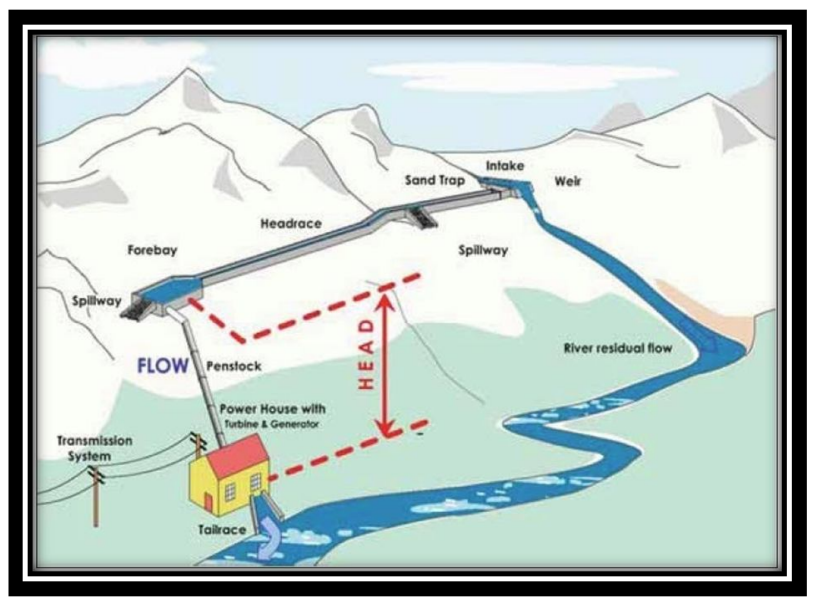

Gambar 2.2 Diagram Skematis PLTMH

Bagian-bagian penting dari PLTMH adalah sebagai berikut :

1. Waduk, berfungsi untuk menahan air

2. Main gate, katup pembuka

3. Bendungan, berfungsi menaikkan permukaan air sungai untuk menciptakan tinggi jatuh air. Selain menyimpan air, bendungan juga dibangun dengan tujuan untuk menyimpan energi.

4. Pipa pesat (penstock), berfungsi untuk menyalurkan dan mengarahkan air ke cerobong turbin. Salah satu ujung pipa pesat dipasang

5. Turbin merupakan peralatan yang tersusun dan terdiri dari beberapa peralatan suplai air masuk turbin, diantaranya sudu (runner), pipa pesat (penstock), rumah turbin (spiral chasing), katup utama (inlet valve), pipa lepas (draft tube), alat pengaman, poros, bantalan (bearing), dan distributor listrik.

6. Generator, Generator listrik adalah sebuah alat yang memproduksi energi listrik dari sumber energi mekanis.

7. Draftube atau disebut pipa lepas, air yang mengalir berasal dari turbin 
8. Tailrace atau disebut pipa pembuangan

9. Transformator adalah trafo untuk mengubah tegangan $\mathrm{AC}$ ke tegangan yang lebih tinggi.

10. Switchyard (controler)

11. Kabel transmisi

12. Jalur Transmisi, berfungsi menyalurkan energi listrik dari PLTMH menuju rumahrumah.

\subsection{Perhitungan dan Analisis Potensi Mikrohidro}

\subsubsection{Perhitungan Daya Listrik}

Menurut (Warsino,S. 2008.Studi Awal Perencanaan Sistem Mekanikal dan Kelistrikan Pembangkit Listrik Tenaga Minihidro, Seminar Nasional, Jurusan Teknik Elektro Fakultas Teknik Industri Universitas Islam Sultan Agun Semarang). Secara teoritis daya listrik yang dapat di hasilkan dari tenaga air mengikuti persamaan berikut :

Daya Teoritis $(\mathrm{P})=\mathrm{Q} \times \mathrm{H} \times \mathrm{g}$

Dimana :

- $\mathrm{Q}=$ Debit Air

- $\quad \mathrm{H}=$ Head

- $\mathrm{g}=$ Konstanta gravitasi

Dengan $\mathrm{P}$ dalam $\mathrm{k} \mathrm{W}, \mathrm{Q}$ dalam $\mathrm{m}^{3} / \mathrm{s}$ dan $\mathrm{g}=$ 9,81 $\mathrm{m} /$ detik. Atau :

$\mathrm{P}=9,81 \times \mathrm{Q} \quad \mathrm{x} \quad \mathrm{H}(\mathrm{kW})$

Sedangkan besarnya energi yang hilang ini di pengaruhi oleh beberapa hal, yaitu :

1. Kerugian / losses pipa pesat / penstock

2. Efisiensi Turbin

3. Efisiensi Generator

4. Efisiensi Trafo

5. Efisiensi Jaringan

6. Efisiensi Sistem Kontrol

7. Efisiensi Konstruksi Sipil

Sehingga persamaan di atas menjadi

P netto $=9,81 \times \mathrm{Q} \times \mathrm{H} \times \mathrm{Et}(\mathrm{KW})$
Dengan P netto adalah Daya listrik yang dapat dimanfaatkan:

$$
\mathrm{Et}=\text { Efisiensi total sistem }
$$

Dari beberapa referensi dapat di ketahui juga bahwa untuk sistem pembangkit kecil, sebagai acuan kasar dapat digunakan harga $\mathrm{Et}=50 \%$. Sehingga di misalkan debit 0,574 dan head 3,62, maka dapat di hitung potensi mikrohidro sebagai berikut :

$$
\begin{aligned}
\text { P netto } & =9,81 \times 0,574 \times 3,62 \times 50 \% \\
& =10,4 \mathrm{KW}
\end{aligned}
$$

\subsubsection{Pengukuran Debit Air}

Terdapat banyak metode pengukuran debit air. Menurut (Sri Sukamta dan Adhi Kusmantoro, Jurnal Teknik Elektro Universitas Negeri Semarang, Jurnal Teknik Elektro Vol. 5 No. 2 Juli - Desember 2013) ; Untuk sistem konversi energi skala besar, pengukuran debit dapat berlangsung bertahun-tahun. Sedangkan untuk sistem konversi energi skala kecil waktu pengukuran dapat lebih pendek, misalnya untuk beberapa musim yang berbeda saja. Pengukuran luas permukaan sungai, dan kecepatan aliran sungai dapat dilakukan dengan langkah-langkah sebagai berikut :

1. Pengukuran kedalaman sungai yang dilakukan di beberapa titik berbeda $\left(\mathrm{X}_{1}-\right.$ $\left.X_{n}\right)$

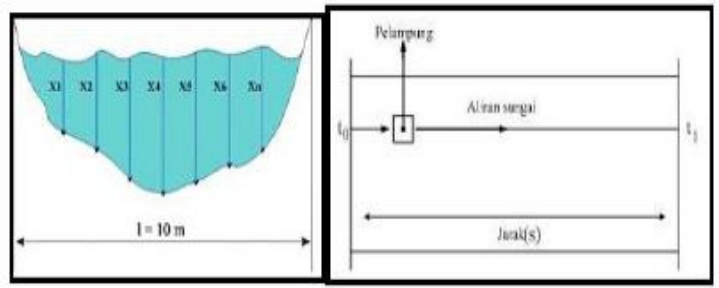

Gambar 2.3 Pengukuran luas permukaan dan kecepatan aliran sungai

2. Jika lebar sungai (L), maka untuk memperoleh luasan dapat dilakukan perhitungan dengan rumusan berikut :

$$
\begin{aligned}
\text { Xrata } & =\frac{\sum x}{n} \\
\text { sehingga A } & (\text { Luasan })=\text { Xrata } \times \mathrm{L}
\end{aligned}
$$


Sedangkan untuk pengukuran kecepatan sungai (v), dapat dilakukan dengan langkah-langkah sebagai berikut :

1. Melakuan pencarian bagian sungai yang aliran airnya lurus dengan panjang sekitar $20 \mathrm{~m}$, namun tidak memiliki arus putar yang dapat menghambat jalannya pelampung.

2. Mengikat sebuah pelampung kemudian dihanyutkan dari titik $\mathrm{t}_{0}-\mathrm{t}_{1}$ (gambar 2.3).

Langkah menentukan kecepatan sungai (v) diatas, dilakukan lima (5) kali berturut-turut, kemudian dilakukan pencatatan waktu tempuh pelampung $\left(\mathrm{t}_{0}-\mathrm{t}_{1}\right)$ dengan menggunakan stopwatch. Untuk perhitungan waktu tempuh rata-rata, digunakan rumusan sebagai berikut :

$$
\mathrm{t}_{\text {rata }}=\frac{\sum t}{n}
$$

sehingga $\mathrm{v}$ diperoleh $:\left(\mathrm{t}_{0}-\mathrm{t}_{1}\right), \mathrm{v}=\frac{s}{t_{\text {rata }}}$, dimana $\mathrm{s}$ adalah jarak sungai

Setelah luas dan kecepatan aliran sungai diketahui, maka besar debit pada sungai tersebut dihitung dengan rumusan berikut :

$$
\mathrm{Q}=\mathrm{A} \times \mathrm{V} \quad\left(\mathrm{m}^{3} / \mathrm{detik}\right)
$$

\subsubsection{Penambahan Kapasitas Mikrohidro}

Menurut (Warsino,S.2008.Studi Awal Perencanaan Sistem Mekanikal dan Kelistrikan Pembangkit Listrik Tenaga Minihidro, Seminar Nasional, Jurusan Teknik Elektro Fakultas Teknik Industri Universitas Islam Sultan Agun Semarang). Untuk meningkatkan daya listrik yang dihasilkan PLTMH dapat digunakan tiga cara, yaitu :
a. Meningkatkan laju aliran (debit) air.
b. Meningkatkan tinggi jatuh (head)
c. Meningkatkan Efisiensi Sistem Pembangkit.

Dari ketiga cara untuk meningkatkan daya output di atas, point yang kedua (b) telah dilakukan pengujian dan paling memungkinkan untuk diterapkan. Beberapa cara dapat digunakan untuk meningkatkan tinggi jatuh (head) ini, diantaranya adalah dengan cara membendung hulu sungai dengan membangun suatu bendungan (dam) kecil. Dengan cara ini tinggi jatuh (head) total sistem instalasi pembangkit dapat di tingkatkan., dan seberapa besar tinggi

Electro Luceat, ISSN: 2527-4724; EISSN : 2597-4467 jatuh (head) dapat di tingkatkan tergantung dari besar dan tingginya bendungan (dam) yang di bangun.

\section{METODE PENELITIAN}

\subsection{Tahapan Penelitian}

Tahapan yang dilakukan dalam penelitian ini digambarkan dalam diagram alur sebagai berikut :

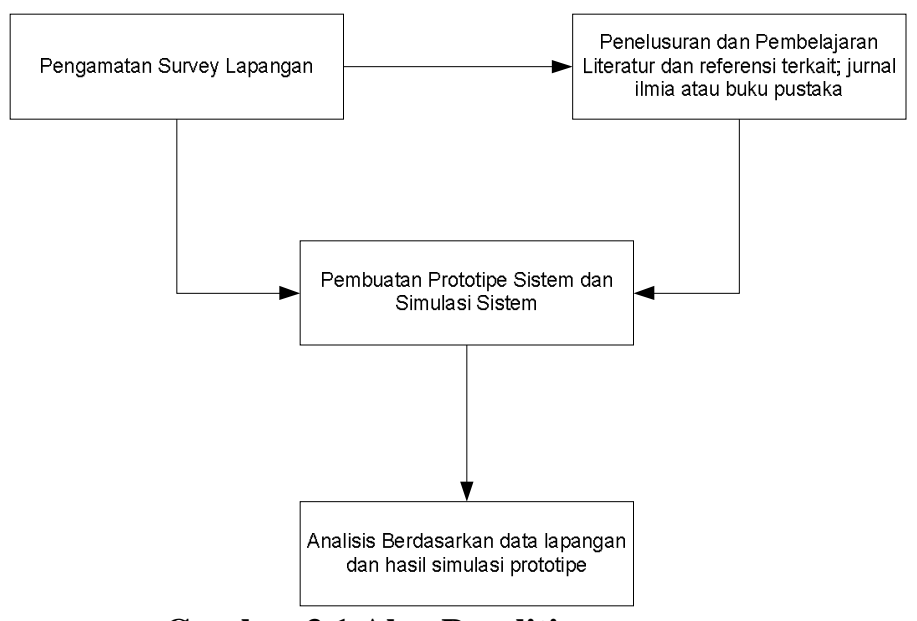

Gambar 3.1 Alur Penelitian

\subsection{Lokasi Penelitian}

Lokasi penelitian ini bertempat di Kampung Sasnek Distrik Sawiat Kabupaten Sorong Selatan, Provinsi Papua Barat, dimana kampung ini memiliki jumlah kk sekitar $170 \mathrm{kk}$.
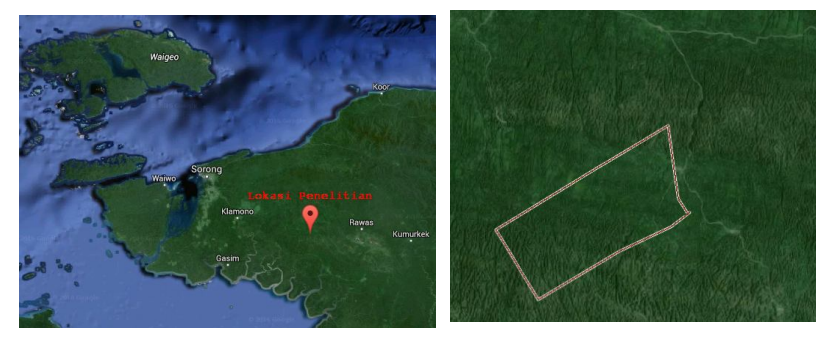

Gambar 3.2 Lokasi Penelitian

\subsection{Desain prototipe PLTMH}

PLTMH:
Berikut rancangan desain prototype 


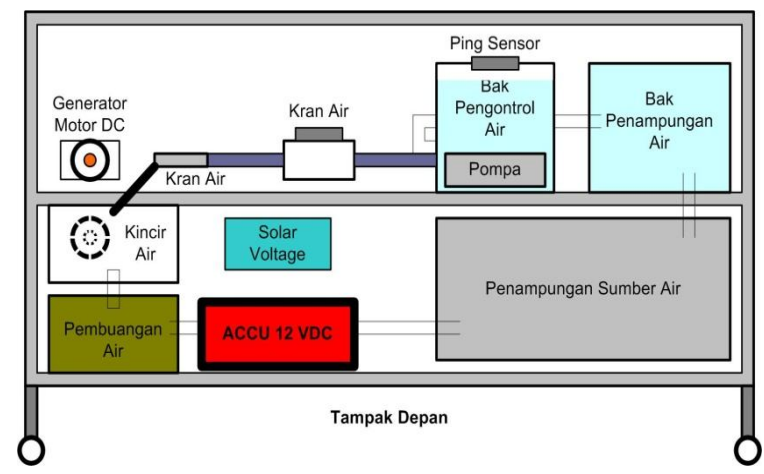

Gambar 3.3 Rancangan Desain untuk Protipe PLTMH

Untuk merancang prototipe PLTMH digunakan pompa air sebagai tekanan (ibarat air terjun), air sebagai sumber energi, turbin dan dinamo DC. Berikut langkah-langkah perancangan prototipe :

\section{A. Perancangan Letak}

Perancangan letak atau kedudukan dari mesin pompa, turbin, motor DC, accu, inverter dan beban. Papan modul yang akan dipakai sebagai tempat meletakan rangkaian-rangkaian terbuat dari bahan mika serta besi berukuran 3 x 3 . Ukuran papan mika sebagai wadah peletakan rangkaian dan besi kotak sebagai rangka meja kerja adalah sebagai berikut :

Meja dari besi kotak $=50 \times 100 \mathrm{~cm}$

Panjang Papan Mika $=100 \times 50 \mathrm{~cm}$

Lebar Papan Mika $=50 \times 100 \mathrm{~cm}$

Tinggi Papan Mika $=100 \mathrm{~cm}$

\section{B. Perancangan Tempat}

Perancangan wadah prototipe di buat dalam dua bagian yang berbentuk box/lemari, yakni :

Blok I / Lantai 1: Terdiri dari Bak pengendap, Valae control 1, saluran pembawa, Valve control 2, bak penenang, Pipa pesat (penstock), dinamo alternator DC 12 Volt, sistim kontrol arduino dan driver motor, serta rangkaian pengukur sensor ketinggian level air.

Blok II / Lantai 2: Bak Penampung Air, Mesin Pompa aquarium, Accu, Turbin mesin pompa dap dan motor bantu.

Untuk rangkaian Kontrol akan di pasang terpisah pada suatu modul menggunakan mika, rangkaian kontrol ini terdiri dari komponen-komponen panel listrik.

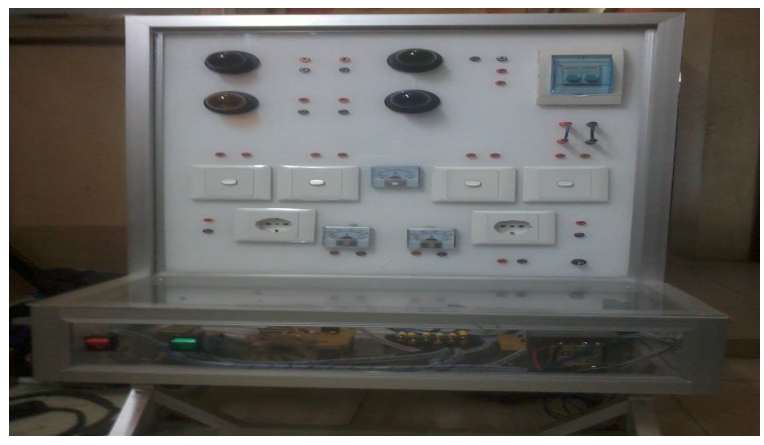

Gambar 3.4 Rangkaian Kontrol

\section{HASIL PENELITIAN}

\subsection{Lokasi Penempatan Daerah}

Lokasi PLTMH berada di Sungai Sasnek yang terletak pada kampung Sasnek, PLTMH Sasnek diperoleh dengan jalan memanfaatkan beda tinggi (head) dan debit aliran air sungai, dimana sungai sasnek merupakan salah satu sungai yang terdapat di daerah Kampung Sasnek, Distrik Sawiat.

\subsection{Kondisi Sosial Ekonomi}

\subsubsection{Mata Pencaharian Masyarakat}

Mata pencaharian masyarakat dapat dibedakan dalam dua kelompok yaitu kelompok masyarakat yang tinggal di Ibukota kabupaten dan kelompok masyarakat yang tinggal disekitar wilayah pinggiran Ibu kota kabupaten. Masyarakat yang tinggal di sekitar ibukota, pada umumnya ada yang bekerja sebagai PNS, pedagang musiman dan nelayan. Sedangkan masyarakat yang tinggal dipedesaan pada umumnya petani, peternak, nelayan dll. Penghasilan rata-rata masyarakat yang bekerja sebagai petani dan peternak dan nelayanper hari rata-rata Rp.100.000, - 250,000 per kepala keluarga sedangkan yang lainnya bervariasi sesuai profesinya masing-masing.

\subsubsection{Kondisi Infrastruktur}

Perkembangan infrastruktur wilayah di Distrik Sawiat, ditunjukkan dengan bertambahnya rumah penduduk, selain diikuti 
dengan perkembangan perbaikan sarana penunjang seperti jalan dan lain sebagainya. Hal ini terjadi secara signifikan setelah terbentuknya Distrik Sawiat.

\subsubsection{Kondisi Elektrifikasi}

Kondisi eletrifikasi di wilayah studi sampai saat ini belum tersedia secara permanen.Adapun listrik yang terdapat di wilayah studi hanya berasal dari generator (genset) dan Solar Sel yang dimiliki oleh orang per orangan ataupun kelompok / oraganisasi tertentu. Hal ini mengakibat pemenuhan kebutuhan listrik di wilayah studi merupakan kebutuhan utama yang sampai saat ini belum dirasakan oleh masyarakat. Keberadaan energy listrik yang dihasilkan oleh generator yang dimiliki secara individual mengalami kendala dalam operasionalnya, selain itu tidak dapat beroperasi selama 24 jam, tingginya harga bahan bakar minyak di wilayah ini, mencapai Rp. 22,000,- 25,000 per liter, merupakan kendala utama atas kondisi elektrifikasi di wilayah ini tentunya selain masalah aksessibilitas.

\subsection{Potensi Hdirolik dan Kapasitas Pembangkit}

\subsubsection{Pengukuran Debit Air}

Daerah sekitar lokasi PLTMH berada pada daerah yang memiliki tingkat curah hujan cukup tinggi. Selain itu didukung juga oleh informasi masyarakat setempat bahwa sungai yang ada mengalir sepanjang tahun, sehingga ketersediaan air tetap terjaga. Untuk mengetahui seberapa besar debit aliran sungai maka dilakukan pengukuran. Langkah pertama yang dilakukan adalah memilih lokasi pengukuran dengan mempertimbangkan kriteria pengukuran debit, setelah di lokasi pengukurannya dilanjutkan dengan pengukuran debit air sungai.

\subsubsection{Pengukuran Beda Tinggi}

Beda tinggi diukur dengan menggunakan alat Handheld Level dan Altimeter Analog yang memiliki tingkat akurasi tinggi. Head dihitung dari level air pada recana bak penenang (forebay) hingga level air pada rencana rumah pembangkit (power house), maka didapat besarnya Head adalah 3 meter.

\subsubsection{Potensi Hidrolik}

Potensi hidrolik adalah potensi energi yang ditimbulkan oleh tekanan air akibat gravitasi bumi. Potensi energi mikro hidro yang tersedia di alam adalah merupakan potensi hidrolik $(\mathrm{Ph})$ dalam bentuk energi potensial. Besarnya potensi hidrolik ditentukan oleh besar debit (Q) dan ketinggian / kemiringan sutau sungai atau head (H).

Secara matematis dapat digambarkan dalam persamaan :

Dimana :

$$
\mathrm{Ph}=\mathrm{g} \times \mathrm{Q} \times \mathrm{H}
$$

$\mathrm{Ph} \quad$ : Potensi Hidrolik, kW

g : gravitasi, $\mathrm{m} /$ detik $^{2}$

Q : Debit air, liter/detik

h : kemiringan/head, meter

\subsubsection{Kapasitas Daya Pembangkit}

Tidak seluruh energi yang dimiliki dalam bentuk potensial hidrolik dapat diubah menjadi tenaga listrik. Pada saat konversi dari energi potensial menjadi energi listrik sebagian energi akan hilang sebagai losess. Selain itu besarnya energi yang dapat diperoleh sangat tergantung pada besarnya efisiensi turbin dan generator yang dapat digunakan. Namun demikian sebagi acuan awal secara sederhana kapasitas daya dapat dihitung dengan persamaan sebagai berikut :

Dimana :

$$
\mathrm{Pel}=\eta \mathrm{tPh}
$$

$$
\begin{array}{ll}
\text { Pel } & : \text { Kapasitas daya terbangkit, } \mathrm{kW} \\
\mathrm{Ph} & : \text { Potensi hidrolik, } \mathrm{kW} \\
\mathrm{\eta t} & : \text { Efisiensi total, } \%
\end{array}
$$

harga nt ditentukan sebesar $76 \%$ diambil dari teori losess pada PLTMH. Dengan demikian hasil perhitungan awal kapasitas daya PLTMH Sawiat dapat di lihat pada tabel dibawah ini : 
Tabel 4.1

Estimasi Kapasitas Daya PLTMH Kampung Sasnek

\begin{tabular}{|c|l|c|c|c|}
\hline NO & Parameter & Simbol & Satuan & Nilai \\
\hline 1. & Debit & $\mathrm{Q}$ & $\begin{array}{c}\text { Liter / } \\
\text { Detik }\end{array}$ & 2 \\
\hline 2. & Head & $\mathrm{H}$ & Meter & 3 \\
\hline 3. & Gravitasi & $\mathrm{G}$ & $\begin{array}{c}\text { Meter } \\
/ \\
\text { Detik }^{2}\end{array}$ & 9.8 \\
\hline 4. & $\begin{array}{l}\text { Efisiensi } \\
\text { Total }\end{array}$ & $\mathrm{T}$ & $\%$ & $75 \%$ \\
\hline 5. & $\begin{array}{l}\text { Kapasitas } \\
\text { Daya }\end{array}$ & Pel & $\mathrm{Kw}$ & 10.000 \\
\hline
\end{tabular}

\subsection{Desain Fasilitas}

\subsubsection{Rencana Bendung (Weir)}

Bendung adalah bagian dari konstruksi sipil yang dibangun membentang sungai yang berfungsi untuk menaikkan level air.Bendung juga berfungsi sebagai pengatur jumlah air yang dibutuhkan pembangkit.

Bangunan bendung dilengkapi sayap dan pintu penguras untuk membersihkan sediment yang menumpuk di dasar bendung. Gaya-gaya yang menjadi bahan pertimbangan dalam desain bendung adalah gaya penggerusan, gaya tekan ke bawah, gaya berat, gaya gempa, daya geser dan gaya hidrostatis.

\subsubsection{Rencana Saluran Penyadap (Intake)}

Saluran penyadap lebih dikenal sebagai bangunan intake adalah bangunan yang terbuat dari pasangan pondasi batu yang di plester dengan bentuk rectangulardengan lebar sesuai dengan kebutuhan air yang digunakan.

Apabila kondisi air sungai yang dibendung sangat banyak sampah maka bangunan ini harus dilengkapi dengan saringan yang terbuat dari besi strip atau begel yang akan berfungsi untuk saringan atau filter. Intake dapat dibangun disisi kiri atau kanan bangunan bendung yang kenal sebagai side intake atau berada di depan bendungan yang disebut direct intake. Struktur intake menggunakan konstruksi pasangan batu kali (1:3) dengan plesteran semen.
Bangunan intake dilengkapi trashrack berupa rangkaian plat besi berbentuk jeruji sebagai penahan dan penyaring sampah serat benda-benda yang tidak diharapkan terbawa bersama aliran air.

\subsubsection{Rencana Saluran Pembawa (Headrace)}

Desain lay-out PLTMH dilengkapi dengan saluran pembawa yang membawa air masuk ke dalam forebay. Namun dalam desain ini hanya menggunakan penstock sebagai saluran masuk ke Turbin.

\subsubsection{Rencana Bak Penenang (Forebay)}

Bak penenang terletak dekat bangunan bendung. Struktur bak penenang berupa pasangan batu kali (1:3) terdiri dari bak pengendap (setting basin), saluran pelimpah (spillway), trashrack dan bak penenang.

Bangunan ini sering dikenal dengan istilah head tank yang berfungsi sebagai reservoir air yang terletak pada sisi atas untuk dialirkan ke unit turbin yang terletak di bagian bawah. Beda tinggi jatuh air antara bagian ini dikenal sebagai Head.

Bak penenang berfungsi untuk mengontrol debit air dalam pipa pesat pada saat terjadi fluktuasi beban, menenangkan aliran air sebelum masuk ke dalam pipa pesat, selain itu juga sebagai penyaringan terakhir sampah dan endapan partikel padat agar tidak masuk ke dalam turbin.

Rencananya pada PLTMH Sasnek fasilitas Bak Penenang di desain sekaligus sebagai Bak Pengendap dengan kapasitas20 - 50 liter/detik.

\subsubsection{Rencana Pipa Pesat (Penstock)}

Pipa pesat adalah pipa bertekanan yang menghubungkan bak penang dengan inlet turbin. Material yang akan digunakan sebagai penstock pada PLTMH Sawiat adalah PVC. Factor yang harus dipertimbangkan dalam desain penstock adalah tekanan, diameter pipa, ketebalan, berat pipa dan kemudahan mobilisasi. Parameter yang diperlukan untuk menentukan diameter pipa pesat adalah : debit air, head, panjang pipa dan sudut rata-rata pipa. 
Setelah diketahui parameter-parameter tersebut maka dengan menggunakan hasil output data tersebut dapat diketahui kecepatan optimum aliran dalam pipa, selanjutnya diameter dan berat pipa pesat dapat dihitung.

Adapun Panjang Pipa Pesat (penstrock) untuk PLTMH Sasnek adalah 100 meter yang diukur dari Bak Penenang - Turbin dengan diameter penstock 8',

\subsubsection{Rencana Ruman Pembangkit (Power House)}

Rumah pembangkit pada skema mikrohidro di desain untuk melindungi peralatan mekanikalelektrikal seperti turbin, generator dan peralatan control elektronik terhadap perubahan cuaca selain itu rumah pembangkit juga harus menyediakan ruang dan kenyamanan bagi operator. Selain itu bagian bawah lantai rumah pembangkit terhubung dengan saluran pembuangan air (tailrace) menuju sungai. Posisi lantai rumah pembangkit berada pada ketinggian yang cukup dari dasar tailrace.

Rencana letak rumah pembangkit PLTMH Sasnekdipilih rumah pembangkit tipe di atas tanah ataupun di dalam tanah dengan ukuran $4 \mathrm{x}$ 8 meter. Pondasi dirancang untuk Turbin Cross Flow oleh karena itu lantai rumah pembangkit diperkuat dengan struktur coran beton bertulang. Adapun konstruksi bangunan berupa pasangan batu dengan plesteran semen. Bangunan rumah pembangkit juga dilengkapi dengan saluran pembuangan (tailrace)sepanjang 20 - 50 meter dengan ukuran 1 x 1 meter.

\subsection{Desain Peralatan Mekanikal - Elektrikal}

Peralatan yang termasuk dalam komponen mekanikal-elektrikal pada PLTMH adalah Turbin, Generator dan Sistem Kontrol / Pengamanan.

\subsubsection{Rencana Turbin}

Berdasarkan hasil desain dan perhitungan untuk skema PLTMH Sasnek ini turbin yang diusulkan untuk digunakan adalah Turbin Crossflow T-14 D 400 yang merupakan produk local (Sorong, Papua) dengan efisiensi turbin mencapai $0.75 \%$, kecepatan poros $2500 \mathrm{rpm}$ dan daya poros turbin $50 \mathrm{Kw}$ menggerakkan generator dengan output $10 \mathrm{~kW}, 220 \mathrm{~V}, 50 \mathrm{~Hz}$, pada kondisi maksimal. Pada turbin ini terdiri dari : Rangka Dasar (base frame), Rumah Turbin Pintu Air (Inlet Valve), Pengatur Pintu Air (Hang Regulator) dan Rotor (Runner). Base frame terbuat dari Mild Steel, Profil "U", dilengkapi dengan angker yang ditanam pada pondasi dan open flume untuk mengarahkan air buangan ke dalam saluran air.

Rumah turbin terbuat dari mild steel, besi plat dengan ketebalan tertentu agar konstruksi turbinnya kokoh. Rotor (runner) terbuat dari besi FCD, pada sisi kiri kanan runner diletakkan bearing yang melekat pada turbin.

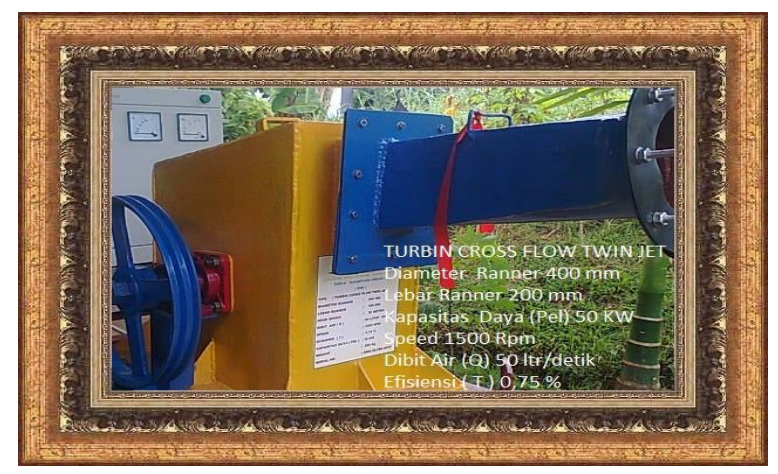

Gambar 4.1. Turbin yang di pakai untuk PLTMH Sasnek

Tabel 4.2

Hasil Perhitungan Kapasitas Daya PLTMH Sasnek Kabupaten Sorong Selatan Berdasarkan Hasil Survey Detail

\begin{tabular}{|l|c|c|c|}
\hline Parameter & Simbol & Nilai & Satuan \\
\hline $\begin{array}{l}\text { Jenis } \\
\text { Turbin }\end{array}$ & Crossflow & & - \\
\hline Tipe & T-14 & & - \\
\hline $\begin{array}{l}\text { Debit } \\
\text { desain }\end{array}$ & Q & 20 & $\begin{array}{c}\text { liter / } \\
\text { detik }\end{array}$ \\
\hline Head & H & 3 & M \\
\hline $\begin{array}{l}\text { Diameter } \\
\text { Runner }\end{array}$ & D & 400 & $\mathrm{~mm}$ \\
\hline $\begin{array}{l}\text { Satuan } \\
\text { Debit }\end{array}$ & Qmax & $20-100$ & $1 /$ detik \\
\hline $\begin{array}{l}\text { Satuan } \\
\text { Kecepatan }\end{array}$ & & & - \\
\hline
\end{tabular}




\begin{tabular}{|l|c|c|c|}
\hline $\begin{array}{l}\text { Lebar } \\
\text { Runner, } \\
\text { mm }\end{array}$ & N & 200 & $\mathrm{Mm}$ \\
\hline $\begin{array}{l}\text { Kecepatan } \\
\text { Turbin }\end{array}$ & $\mathrm{N}$ & 1500 & $\mathrm{Rpm}$ \\
\hline $\begin{array}{l}\text { Efisiensi } \\
\text { Turbin }\end{array}$ & $\mathrm{Ntur}$ & 0,75 & Fraksi \\
\hline $\begin{array}{l}\text { Efisiensi } \\
\text { Transmisi } \\
\text { Mekanik }\end{array}$ & Ntrm & 0,95 & Fraksi \\
\hline $\begin{array}{l}\text { Efisiensi } \\
\text { Generator }\end{array}$ & $\mathrm{Ngen}$ & 0,9 & $\mathrm{Fraksi}$ \\
\hline $\begin{array}{l}\text { Potensi } \\
\text { Hidrolik }\end{array}$ & Ph & 3 & $\mathrm{~kW}$ \\
\hline $\begin{array}{l}\text { Kapasitas } \\
\text { Daya } \\
\text { Turbin }\end{array}$ & Ptur & 50 & $\mathrm{~kW}$ \\
\hline $\begin{array}{l}\text { Kapasitas } \\
\text { Daya } \\
\text { Generator }\end{array}$ & Pgen & 10 & $\mathrm{~kW}$ \\
\hline
\end{tabular}

(Lihat Lampiran : TURBINE SPECIFICATIONS : CROSSFLOW T-14 D400)

\subsubsection{Rencana Generator}

Pada PLTMH Sasnek putaran poros turbin dari hasil perhitungan debit air adalah sebesar 2 liter/detik, sedangkan putaran yang diperlukan generator untuk dapat menghasilkan daya listrik adalah sebesar 1500 rpm maka dengan cara meningkatkat laju aliran debit dan Volume air diperlukan pemasangan bak Penampung Cadangan dengan menaikan kapasitas Penampungan-nya. Transmisi mekanik PLTMH Sasnek berbentuk pulley dengan rasio diameter sesuai yang dihubungkan dengan $\mathrm{V}$-Belt.

Adapun spesifikasi teknis dari Generator PLTMH Sasnekadalah sebagai berikut : Generator Sinkron AC 1 phase $220 \mathrm{~V}, 50 \mathrm{~Hz}$ $1500 \mathrm{rpm}$, factor daya 1 x $10 \mathrm{~kW}$, kapasitas generator sebesar $10 \mathrm{~kW}$.

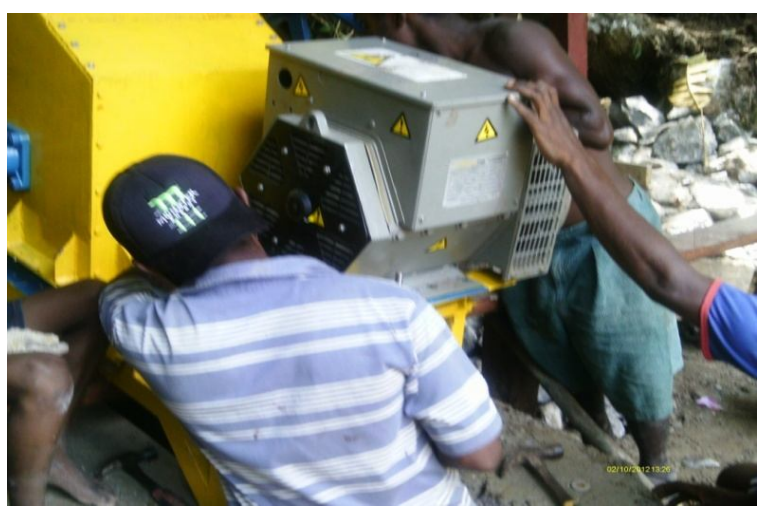

Gambar 4.2 Rencana Bentuk Generator

\subsubsection{Rencana Sistem Kontrol dan Pengamanan}

Mengingat lokasi PLTMH Sasnek berada di daerah terpencil maka system control digunakan jenis control yang lebih dikenal dengan Electronic Load Controller (ELC). Dengan system ini fluktuasi beban akan diatur dan disesuaikan secara otomatis oleh ELC.

\section{Tabel 4.3}

RENCANA SPESIFIKASI TEKNIS PEKERJAAN JARINGAN TRANSMISI Pekerjaan Pembangunan 1 (satu) Unit PLTMH Sasnek Kabupaten Sorong Selatan

\begin{tabular}{|ll|l|}
\hline \multicolumn{2}{|c|}{ Jaringan Transmisi } \\
\hline - & Panjang Jaringan & 3000 meter \\
- & Tegangan & 220 Volt \\
- & Jenis / Ukuran Kabel & Tic Kabel 2 x 70 \\
- & Jenis Tiang & mm \\
- & Jumlah Tiang & Besi (Standart \\
- & Aksessories & Jaringan JTM) \\
- & Grounding & / \\
& Earthing Batang \\
& & SPLN \\
\hline
\end{tabular}

Tabel 4.4

RENCANA SPESIFIKASI TEKNIS JENIS

TURBIN YANG AKAN DI PAKAI

Pekerjaan Pembangunan 1 (satu) Unit PLTMH Sasnek Kabupaten Sorong Selatan

\begin{tabular}{|ll|l|}
\hline \multicolumn{2}{|c|}{ Turbin } \\
\hline - & Tipe & Crossflow T-14 D 300 \\
- & Daya & $50 \mathrm{~kW}$ \\
- & Unit Speed & 38.00 \\
- & Head Gross & 3 meter \\
\hline
\end{tabular}




\begin{tabular}{|ll|l|}
\hline - & Debit Air Optimum & $20-100$ liter / detik \\
- & Kecepatan Turbin & $2500 \mathrm{rpm}$ \\
- & Efisiensi & 0.75 \\
\hline
\end{tabular}

Tabel 4.5

RENCANA SPESIFIKASI TEKNIS JENIS

GENERATOR, SISTEM KONTROL DAN

TRANSMISI MEKANIK

Pekerjaan Pembangunan 1 (satu) Unit PLTMH

Sasnek - Sawiat

Kabupaten Sorong Selatan

\begin{tabular}{|ll|l|}
\hline \multicolumn{2}{|c|}{ Generator } \\
\hline - & Jenis & AC Sinkron 1 Phase \\
- & Rating Power & $1 \times 10 \mathrm{~kW}$ \\
- & Frekuensi & $50 \mathrm{~Hz}$ \\
- & Phase / Pole & Standar \\
- & Kecepatan Poros & 1 Phase \\
- Tegangan & $1500 \mathrm{rpm}$ \\
- & Power Faktor & $220 \mathrm{Volt}$ \\
- & Efisiensi & 0,8 Frasi \\
\hline
\end{tabular}

\begin{tabular}{|ll|l|}
\hline \multicolumn{2}{|c|}{ Sistem Kontrol } \\
\hline - & Tipe & ELC \\
- & Rating Power & $10 \mathrm{~kW}$ \\
- Tegangan & 220 Volt \\
\hline
\end{tabular}

\begin{tabular}{|c|c|}
\hline \multicolumn{2}{|c|}{ Transmisi Mekanik } \\
\hline $\begin{array}{lll}\text { - } & \text { Putaran } & \text { Poros } \\
& \text { Turbin } & \\
\text { - } & \text { Putaran } & \text { Poros } \\
& \text { Generator } & \\
\text { - } & \text { Rasio Pulley } & \\
\text { - } & \text { Jenis / Tipe Belt }\end{array}$ & $\begin{array}{l}\text { rpm } \\
1500 \mathrm{rpm} \\
1,5 \\
\text { V-Belt }\end{array}$ \\
\hline
\end{tabular}

\subsection{Desain Jaringan Transmisi}

Parameter utama dalam desain jaringan transmisi pada pembangkit mikrohidro adalah menentukan panjang jaringan, besar tegangan (jaringan tegangan rendah JTR atau jaringan tegangan menengah JTM), jenis dan ukuran kabel, jenis tiang ( besi ), tinggi tiang dan jumlah tiang.

Jaringan transmisi untuk PLTMH Sasnek digunakan Jaringan Tegangan Menengah (JTM) 240 Volt sepanjang 3000 meter.

Electro Luceat, ISSN: 2527-4724; EISSN : 2597-4467
Kabel digunakan jenis Alumunium dengan Conductance (tahanan) sebesar $36.72 \mathrm{MS} / \mathrm{m}$ ditopang oleh tiang besi (Standart JTM - PLN) dengan tinggi 12 meter sebanyak \pm 300 batang.

\subsection{Rencana Anggaran Biaya Rehabilitasi PLTMH Sasnek}

Adapun prakiraan Anggaran biaya untuk kegiatan Pembangunan PLTMH Sasnek, Distrik Sawiat Kabupaten Sorong Selatan adalah sebesar 2.370.046.000.00, Rencana Anggaran Biaya (RAB) ini dihitung berdasarkan kondisi ekonomi tahun 2016 yang datanya diambil dari Basic PriceMaterialyang dikeluarkan oleh Pemerintah Kabupaten Sorong SelatanTahun 2016.

Sebagai catatan besarnya biaya Pembangunan PLTMH Sasnek Distrik Sawiat di Kabupaten Sorong Selatan disebabkan karena Aksessibilitas Barang / Jasa di wilayah ini hanya dapat dicapai dengan menggunakan sarana Transportasi Darat dan laut .

\section{KESIMPULAN}

1. Setelah dilakukan pengukuran debit air, didapat debit sebesar 2 liter/detik dari luas area pengukuran $5 \mathrm{~m}^{2}$ dan kecepatan air rata-rata $00.65 \mathrm{~m} / \mathrm{d}$. Namun karena kondisi air sungai yang mengalir sepanjang tahun dalam arti tidak pernah kering, maka digunakan faktor koreksi 0.75. Dengan demikian debit yang bisa dimanfaatkan adalah sebesar $0.65 \mathrm{~m}^{3} / \mathrm{d}$.

2. Berdasarkan hasil analisa terhadap potensi PLTMH yang terdapat di Sasnek, maka dapat dikalkulasikan Distribusi Jaringan Listrik yang bersumber dari PLTMH Sasnek adalah $10 \mathrm{KW}$.

\section{DAFTAR PUSTAKA}

Napitupulu Janter. 2012. Pembangkit Listrik Tenaga Mini Hidro (Pltm) Dalam Pengelolaan Energi Hijau. Jurnal DA, Jurusan Teknik Elektro Universitas Darma Agung Medan. : JDA 21-25

Parabelem T.D. R. 2011. Analisis Pembangkit Listrik Tenaga Mikrohidro (PLTMH) Pada 
Daerah Aliran Sungai Ongkak Mongondow Di Desa Muntoi Kabupaten Bolaang Mongondow. Jurnal Penelitian Saintek. 16 (2): 160-171.

Setyo Putro Yogi Suryo, Tri Juwono Pitojo, Hadi Wicaksono Prima. 2012. Studi Perencanaan Pembangkit Listrik Tenaga Mikro Hidro (Pltmh) Di Sungai Atei Desa Tumbang Atei Kecamatan Sanamang Mantikai Kabupaten Katingan Provinsi Kalimantan Tengah. Jurnal Ilmiah Universitas Brawijaya. 48 (2): 24-35.

Sukamta Sri, Kusmantoro Adhi. 2013. Perencanaan Pembangkit Listrik Tenaga Mikro Hidro (PLTMH) Jantur Tabalas Kalimantan Timur. Jurnal Teknik Elektro Universitas Negeri Semarang. 5 (2) : 58-63.

Tobi, Markus Dwiyanto. "PENGARUH OPTIMASI TRANSFORMATOR DAYA TERHADAP PERKEMBANGAN BEBAN FEEDER UNTUK MEMINIMALISASI GANGGUAN DAN DEFISIT BEBAN LISTRIK DI WILAYAH SORONGPROVINSI PAPUA BARAT." Electro Luceat 3.1 (2017): 10-18.

Warsino, S. 2008. Studi Awal Perencanaan Sistem Mekanikal dan Kelistrikan Pembangkit Listrik Tenaga Minihidro. Seminar Nasional, Jurusan Teknik Elektro Fakultas Teknik Industri Universitas Islam Sultan Agung Semarang. 